\title{
Syncope in Children and Adolescents
}

\author{
Ljiljana Pejčić ${ }^{1}$, Marija Ratković Janković ${ }^{1}$, Radmila Mileusnić-Milenović \\ Karin Vasić ${ }^{1}$ Ivana Nikolić ${ }^{1}$ \\ ${ }^{1}$ Clinic of Children's Internal Diseases, Clinical Center Niš, Niš, Serbia \\ ${ }^{2}$ Institute of Neonatology, Belgrade, Serbia
}

\section{SUMMARY}

In the pediatric age group, most cases of syncope represent benign, neutrally-mediated alterations in vasomotor tone. Due to the global cerebral hypoperfusion, syncope is defined as a transient loss of consciousness followed by spontaneous recovery and/or a state of presyncope, including dizziness, lightheadedness, pallor, diaphoresis and palpitations which may precede the loss of consciousness. These symptoms could be a sign of a life-threatening event in a small subset of patients, even though most causes of syncope in childhood are benign, and life-threatening causes of syncope generally have cardiac etiology. In all these cases, routine evaluation includes history, physical examination and a 12-lead standard electrocardiogram which should be performed. Further investigation is indicated by worrying features which include syncope that occurs without warning, syncope during exercise, history of familial sudden death, and abnormalities on clinical exam or electrocardiography. The fact is that syncope generates great fear of injury or sudden death among parents and doctors, and the main aim of the present paper is to help the physician involved in the care of children to differentiate the life-threatening causes of syncope from the common, more benign neutrally-mediated syncope.

Key words: syncope, children, adolescents

Corresponding author:

Ljiljana Pejčić

Email: ljiljasonja@yahoo.com 


\section{INTRODUCTION}

Syncope is defined as a sudden and transient loss of consciousness due to the global cerebral hypoperfusion followed by spontaneous recovery (1). Other states of altered consciousness, such as seizure, coma, vertigo and hypoglycemia are excluded by this definition. Sudden reduction in the delivery of oxygen to the brain is a cause of loss of consciousness and subsequent fall of the patient, if he/she is not supported. It may be preceded by a state or presyncope, including dizziness, lightheadedness, pallor, diaphoresis, and palpitations. About $15-25 \%$ of children and adolescents experience at least one syncope episode by young adulthood, which makes syncope a common complaint among teenagers and it is more common among females $(2,3)$. Its peak incidence is between 15 to 19 years and it is not common before the age of six.
In very young children, syncope is usually seen in patients with seizure disorders, breath-holding episodes and primary cardiac arrhythmias.

As syncope generates great fear of injury or sudden death among the parents and doctors, the main goal of the present paper is to help the physician involved in the care of children to differentiate the lifethreatening causes of syncope from the common, benign, neutrally-mediated syncope.

\section{ETIOLOGIES OF SYNCOPE}

Although there are different potential causes of syncope, the majority of syncopal attacks can be classified into three major categories: neurally-mediated syncope (NMS), cardiovascular and non-cardiovascular syncope (Table 1) (4).

Table 1. Causes of syncope in childhood and adolescents

\begin{tabular}{l}
\hline \hline I Neurally-mediated syncope \\
\hline II Cardiovascular syncope \\
\hline 1. Primary morphological heart disease \\
Left ventricular outflow obstruction \\
Right ventricular outflow obstruction \\
Pulmonary hypertension \\
Myocardial dysfunction (cardiomyopathy, myocarditis) \\
2. Arrhythmias \\
Tachyarrhythmias \\
Long QT syndrome \\
Brugada syndrome \\
Wolff-Parkinson-White syndrome \\
Supraventricular tachycardia \\
Ventricular tachycardia \\
Bradyarrhythmias \\
Sick sinus syndrome \\
Heart block \\
\hline III Non-cardiovascular syncope \\
Migraine \\
Drug abuse \\
Hysteria \\
Hyperventilation \\
Situational (cough, micturition, stretch, hair grooming, defecation) \\
Breath-holding spells \\
\hline \hline
\end{tabular}


The most common cause of fainting in otherwise healthy children and adolescents (60-80\%) is NMS (synonyms: vasovagal syncope, vasodepressor syncope neurocardiogenic syncope, reflex syncope) $(5,6)$.

Sudden loss of vasomotor tone with resultant systemic hypotension (the vasodepressor response)accompanied by significant bradycardia or asystole (the cardioinhibitory response) is the physiological pathway of NMS.

A mixed picture consisting of significant systemic hypotension associated with paradoxical bradycardia is characteristic of the majority of pediatric patients. A prodrome of premonitory symptoms, due toautonomic activity such as light headedness, giddyness, nausea and shortness of breath, pallor or even changes in vision, are usually reported by older children and those with recurrent syncopalepisodes.

The upright position, such as prolonged period of standing or change in posture (orthostasis) can be the reason for most episodes. Commonly associated triggers for fainting in children can be also emotional or stress factors such as venepuncture, public speaking, pain and fear. Fatigue, hunger, concurrent illness and dehydration also can be the provocative factors for vasovagal syncope. Duration of loss of consciousness is short, no more than 1 to 2 minutes. It is accompanied by relatively rapid recovery or some patients may have a residual headache, nausea, giddiness and fatigue.

Vasodepressor syncope usually occurs immediately after the termination of an activity, when it is associated with exercise, and has been well described in pediatric patients (7).

Syncope which may be a clue to the presence of the underlying cardiac problem and may predict a risk of sudden death (8) appears in a very few cases and, luckily, cardiac disorders represent only $2-6 \%$ of the cases $(6,9)$.

Cardiac causes can be separated into two categories. The first category is primary cardiac anomalies (right or left heart obstruction, pulmonary hypertension, cyanotic crisis in cyanotic heart defects, hypertrophic or congestive cardiomyopathies). The second one is arrhythmias that can lead to syncope in many conditions (long QT syndrome, Brugada syndrome, postoperative arrhythmias, Wolff-Parkinson-White syndrome, and rarely, idiopathic ventricular tachycardia (VT) or VT associated with arrhythmogenic right ventricular dysplasia) (Table 1) $(4,10,11)$.

\section{CLINICAL EVALUATION}

The most specific and sensitive ways of evaluating syncope are history and physical examination and these two measures, as well as 12-lead electrocardiography (ECG), were the only current level Arecommendations listed in the 2007 American College of
Emergency Physicians (ACEP) Clinical Policy on Syncope (12).

There are elements that suggest potential cardiac disease as a cause of syncope. One of them is family history of premature or unexplained sudden death, known familial arrhythmia (long QT syndrome) or heart disease (cardiomyopathy). Another one is prior history of known structural heart disease, known arrhythmia, or suspected heart disease (recent fatigue, exercise intolerance) $(6,9)$. Very important is an event history and there are clinical features that suggest the underlying cardiac problem. These features are: little or no prodrome, prolonged loss of consciousness (longer than $5 \mathrm{~min}$ ), exercise-induced syncope, chest pain or palpitations, event requiring cardiopulmonary resuscitation or resulting in neurological sequelae $(13,14)$.

It was mentioned before that NMS associated with exercise does exist, but a more serious cardiac cause should always be eliminated in exercise-related syncope.Supine and standing blood pressures as well as a complete cardiac examination should be included in the physical examination, while irregular rhythm, patholo-gical murmur or abnormal heart sound are the elements suggesting that potential cardiac diseases are the cause of syncope (6).

As for the cases of children with particular attention to the rhythm and to the potential presence of a delta wave or a prolonged QT interval as well as T wave morphology (Brugada syndrome), all initial evaluations of syncope should routinely include an electrocardiogram.

Conduction disorders and some cases of Brugada syndrome, or some suspected underlying structural cardiac abnormalities may also be identified, besides the long QT syndrome and ventricular preexcitation. Left or right ventricular hypertrophy could be useful for the evaluation of obstructive cardiac lesions or cardiomyopathies $(6,14)$. Frequentectopy, VT, supraventricular tachycardia, bradycardia, intermittent WPW, heart block or pauses could be eliminated by a $24 \mathrm{~h}$ ambulatory ECG monitoring in cases of suspected arrhythmia (15). The task of echocardiogram is to rule out malformations or cardiomyopathies.

In most cases, when the history, physical examination and ECG suggest NMS, no further diagnostic tests are needed. The evaluation of pediatric syncope sometimes is very expensive, and testing has a low diagnostic field. The tilt-table test is used as a method for the evaluation of syncope of unknown cause and it usually confirms the diagnosis of NMS. Its use in pediatrics is controversial due to the fact that several groups have demonstrated sensitivities of $43 \%$ to $57 \%$ and specificities of $83 \%$ to $100 \%$ (16).

The goal of investigation in the cases of syncope of unknown origin is to rule out life-threatening causes rather than to diagnose NMS. This is the reason why the echocardiography is more useful than the tilt-table test 
(17). An exercise stress test is mandatory for exerciseinduced syncope to look for the ST- T wave changes that are associated with coronary insufficiency and catecholamine-sensitive dysrhythmias (18).

\section{TREATMENT}

Each individual should have his own tailored treatment. Patients and parents must be educated about benign nature of NMS, advised how to recognize prodromal symptoms and how to avoid triggers. That means that education represents an important effort. In the cases when a prodromal phase is consistently present, a patient may get the instructions how to recline or sit to avoid injury from a fall. Water and salt intake which can increase plasma volume (1.5-2.5 liters of fluid are recommended) present the next simple measures. In the cases in which conservative therapy fails, there is medical therapy which can be used. Medical therapy usually includes a beta-blocker, fludrocortisone, anticholinergics, alpha agonists and serotonin uptake inhibitors. The rule is that potentially toxic drugs should be avoided; however, disopyramide has been used with success in some cases (19). Pacemaker therapy is rarely used.

The prognosis for recovery in NMS is excellent and most patients show spontaneous recovery of their syncope and presyncope in the first year after the onset. Symptoms in 5-10\% patients last for over an extended period of time, often up to five years. The therapy is usually more clearly defined and directed to the underlying cause for cardiac syncope and it includes betablocker therapy in cases of long QT syndrome, medical therapy for some forms of cardiomyopathy, surgical resection for cardiac obstructive lesions and pacemaker therapy for a sick sinus or heart block. In the cases of resuscitated cardiac arrest or high risk familial disease (such as long QT syndrome, Brugada syndrome and hypertrophic cardiomyopathy), an implantable defibrillator is required (6).

\section{CONCLUSION}

Syncope in children is most often neurally-mediated and usually has a natural history of spontaneous resolution or improvement. Anxiety about epilepsy or sudden death from this condition, which is a usual reaction of the patient and parents, can be allied by exact explanation of the benign nature of these events to them. It is not a rare case that primary care physician diagnoses and treats otherwise healthy children and adolescents who have experienced syncope. Further investigation by a cardiologist should be led by the following markers: syncope that occurs with exercise, syncope that occurs without warning (no dizziness, muffled hearing or visual changes), syncope that results in a serious injury, a family history of sudden unexplained death, cardiomyopathy or congenital heart disease and an abnormal cardiac examination or electrocardiogram. It is up to the cardiologist to determine whether a patient's complaint of syncope and /or dizziness has a life-threatening cause. 


\section{References}

1. Walsh K, Hoffmayer K, Hamdan MH.Syncope: diagnosis and management. CurrProblCardiol 2015;40:51-

86.https://doi.org/10.1016/j.cpcardiol.2014.11.001

2. Manolis AS. Evaluation of patients with syncope. Focus on age-related differences. J Am CollCardiol 1994;3:13-8.

3. Driscoll DJ, Jacobsen SJ, Porter CJ, et al. Syncope in childrenand adolescents. J Am CollCardiol 1997; 29:1039-45.

https://doi.org/10.1016/S0735-1097(97)00020-X

4. Cote JM.Syncope in children and adolescents: Evaluation and treatment. Pediatr Child Health 2001; 68:549-51.

https://doi.org/10.1093/pch/6.8.549

5. Pratt JL, Fleisher GR. Syncope in children and adolescents. PediatrEmerg Care 1989;5:80-2 https://doi.org/10.1097/00006565-198906000-00002

6. Massin MM, Bourguignont A, Coremans C, et al. Syncope in pediatric patients presenting to an emergency department. J Pediatr 2004;45:223-7. https://doi.org/10.1016/j.jpeds.2004.01.048

7. Calkins H, Seifert M, Morady F. Clinical presentation and long-term follow-up of athletes with exercise-induced vosodepressor syncope. Am Heart J 1995; 129:1159-1164. https://doi.org/10.1016/0002-8703(95)90398-4

8. Friedman KG, Alexander ME. Chest pain and syncope in children: a practical approach to the diagnosis of cardiac disease. J Pediat. 2013; 163:896-901. https://doi.org/10.1016/j.jpeds.2013.05.001

9. Moya A, Sutton R, Ammirati F, et al. Guidelines for the diagnosis and management of syncope (version 2009): the Task Force for the Diagnosis and Management of Syncope of the European Society of Cardiology (ESC). Eur Heart J 2009; 30:2631-71. https://doi.org/10.1093/eurheartj/ehp298

10. Massin MM, Malekzadeh-Milani S, Benatar A., Cardiac Syncope in Pediatric Patients. Clin. Cardiol2007; 30:81-5.

\section{https://doi.org/10.1002/clc.28}

11. Wolff GS. Unexplained syncope: Clinical management. Pacing ClinElectrophysiol 1997; 20: 20432047.

https://doi.org/10.1111/j.1540-8159.1997.tb03624.x

12. Huff JS, Decker WW, Quinn JV et al. Clinical policy: critical issues in the evaluation and management of adult patients presenting to the emergency department with syncope. Ann Emerg Med 2007; 494:43144.

https://doi.org/10.1016/j.annemergmed.2007.02.001

13. Johnsrude CL. Current approach to pediatric syncope. Pediatr Cardiol 2000; 21:522-31. https://doi.org/10.1007/s002460010130

14. Villain E. Cardiac syncope in children. Arch Pediatr 2004;11:169-74.

https://doi.org/10.1016/j.arcped.2003.10.017

15. Gibson TC, Heitzman MR: Diagnostic efficacy of 24hour electrocardiographic monitoring for syncope. Am J Cardiol 1984; 53:1013-7. https://doi.org/10.1016/0002-9149(84)90628-3

16. Lewis AL, Zlotocha J, Henke L. Specificity of headup tilt testing in adolescents: Effects of various degrees of tilt challenge in normal control subjects. J Am CollCardiol 1997; 30:1057-60. https://doi.org/10.1016/S0735-1097(97)00255-6

17. Tretter JT, Kavey RE. Distinguishing cardiac syncope from vasovagal syncope in a referral population. J Pediatr. 2013; 163:1618-23. https://doi.org/10.1016/j.jpeds.2013.07.023

18. Luckstead EF. Cardiovascular evaluation of the young athlete. Adolesc Med 1998; 9:441-55

19. Morillo CA, Leitch JW, Yee $\mathrm{R}$ et al. A placebocontrolled trial of intravenous and oral disopyramide for prevention of neurally-mediated syncope induced by head-up tilt. J Am CollCardiol 1993; 22:1843-8.

https://doi.org/10.1016/0735-1097(93)90767-U 


\title{
Sinkopa kod dece i adolescenata
}

\author{
Ljiljana Pejčić1, Marija Ratković Jankovićn ${ }^{1}$ Radmila Mileusnić-Milenović², \\ Karin Vasić1 ${ }^{1}$ Ivana Nikolić ${ }^{1}$
}

\author{
${ }^{1}$ Klinika zadečije interne bolesti, Klinički centar Niš, Niš, Srbija \\ 2Institut za neonatologiju, Beograd, Beograd, Srbija
}

\section{SAŽETAK}

Sinkopa u pedijatrijskoj populaciji najčešce je benigna, neurološki posredovana promena vazomotornog tonusa. Definiše se kao prolazni gubitak svesti usled globalne cerebralne hipoperfuzije, posle čega dolazi do spontanog oporavka. Obično joj prethodi stanje koje nazivamo presinkopa, a koje karakteriše vrtoglavica, nesvestica, bledilo, dijaforeza ili lupanje srca. Iako je većina sinkopa u detinjstvu benigna, kod malog broja bolesnika mogu biti znak ozbiljnog oboljenja koje ugrožava život. Ove životno ugrožavajuće sinkope su uglavnom kardiovaskularnog porekla. Rutinska ispitivanja uključuju adekvatno uzetu anamnezu, fizikalni pregled i 12-kanalni elektrokardiogram kod svih bolesnika. Upozoravajući znaci koji zahtevaju dalju dijagnostiku su sinkopa koja se javlja u naporu, sinkopa bez prodroma, iznenadna srčana smrt u porodičnoj anamnezi, abnormalnosti u kliničkom pregledu i elektrokardiogramu. Kako je sinkopa stanje koje generiše veliki strah od povrede ili iznenadne srčane smrti, kako kod roditelja tako i kod lekara, glavni cilj ovoga rada je da pomogne pedijatru koji leči dete da razlikuje sinkope koje ugrožavaju život deteta od benignih, neurološki posredovanih sinkopa.

Ključnereči : sinkopa, deca, adolescenti 